\title{
PELUANG DAN TANTANGAN MEA: KERJASAMA PENDIDIKAN INDONESIA DI KAWASAN ASEAN
}

\author{
Dr. H. Zainal Abidin, M.Ag \\ Program Pascasarjana Sekolah Tinggi Agama Islam Negeri (STAIN) \\ Jurai Siwo Metro \\ zainaltob@yahoo.co.id
}

\begin{abstract}
The 12th KTT ASEAN (ASEAN Summit) at Cebu emphasized to create MEA 2015 which makes South East Asia as free flow of goods and services zone, investment and skilled labor, and freer flow of capital. As the impact, Indonesia will face the foreign labor invasion as the result of developed country education like as Singapore. In facing this competition, Indonesia government formulate national education strategy with the purpose that the human resources can compete in the world of global business, at least should refer to determinant factors of nation, such as innovation mastery $(45 \%)$, network mastery $(25 \%)$, technology mastery (20\%), and natural resource wealth mastery $(10 \%)$. Islamic Collage Publics have opened international class and they have prepared the lecturers who appropriate with international qualification and standard. Islamic Collage Publics also prepare their students with intellectual ability including English and Arabic language mastery and as the result they can compete with ASEAN Countries.
\end{abstract}

Key Words: Education Coorporation, Education, Collage Institution, Economic ASEAN Society, Human Resources.

\begin{abstract}
Abstrak
KTT ASEAN (ASEAN Summit) ke 12 di Cebu menegaskan komitmen untuk membentuk MEA tahun 2015 yang menjadikan kawasan Asia Tengggara sebagai kawasan bebas aliran barang dan jasa, investasi, dan tenaga terampil, serta aliran modal yang lebih bebas. Sebagai akibatnya, Indonesia akan menghadapi serbuan para pekerja asing hasil output pendidikan dari negara maju seperti Singapura. Untuk menghadapi persaingan ini, pemerintah Indonesia merumuskan strategi pendidikan nasional supaya SDM Indonesia dapat bersaing dalam dunia kerja global, paling tidak harus mengacu pada faktor penentu kemajuan suatu bangsa atau negara, yaitu: penguasaan innovasi (45\%), penguasaan jaringan 25\%, penguasaan teknologi $20 \%$, dan penguasan kekayaan sumber daya alam hanya 10\%. Dalam konteks PTKIN (Perguruan Tinggi Keagamaan Islam Negeri), mereka telah membuka kelas-kelas internasional, dan telah mempersiapkan SDM pengajarannya sesuai dengan standar dan kualifikasi Internasional. PTKIN juga membekali mahasiswanya dengan kemampuan intelektual yang baik termasuk kemampuan penguasaan bahasa Asing terutama Inggris dan Arab agar mampu berkompetisi dengan output pendidikan sejenis dari negara-negara di kawasan ASEAN.
\end{abstract}

Kata kunci: Kerjasama Pendidikan, Pendidikan, Lembaga pendidikan tinggi, masyarakat ekonomi ASEAN (MEA), Sumber Daya Manusia (SDM). 


\section{Pendahuluan}

Ciri masyarakat pada era globalisasi sebenarnya telah diprediksi oleh Alvin Tofler dan Patricia Aburdance pada era 1990-an. Prediksi ini muncul sebagai akibat perubahan politik antara Negara-negara yang tergabung dalam dua blok Besar, yaitu Blok Barat yang dipimpin oleh Amerika Serikat, dan Blok Timur yang dipimpin oleh Uni Sovyet (Rusia) dan sekutu-sekutunya yang kebanyakan sekarang telah menjadi Negara-negara merdeka bekas Uni Sovyet di kawasan Eropa Timur (Balkan, Chekoslovakia Polandia dan sebagainya), termasuk negara-negara besar Sovyet di Asia Tengah. "Perang Dingin" antara Blok Barat dan Blok Timur ini berakhir setelah terjadi perubahan politik, dan akibat tekanan ekonomi di negara-negara Eropa Timur, termasuk yang dialami oleh Sovyet sendiri yang mengalami krisis ekonomi sejak tahun 19891 dan berakhir tahun 1990 yang ditandai oleh pecahnya Uni Sovyet menjadi beberapa negara yang melepaskan diri dari Sovyet, serta revolusi rakyat menentang Sovyet dan pengaruhnya di beberapa Negara Eropa Timur, antara lain di Rumania dan Austria, Bulgaria, Chekoslovakia serta Jerman Timur, dan yang ditandai oleh runtuhnya "Tembok Berlin" pada akhir tahun 1989. Peristiwa itu juga menandai kemenangan Blok Barat atas Blok Timur. Sejak saat itu, era Globalisasi dimulai, berbagai upaya dilakukan dalam menyongsong perubahan abad, dari abad 20 ke abad $21 .^{2}$

Prediksi John Naisbit dan Patricia Aburdene menjadi terkenal sekali melalui karyanya Megatrends 2000, dan diterjemahkan dalam berbagai bahasa dunia, karena larisnya buku tersebut pada awal tahun 1990, termasuk edisinya dalam bahasa Indonesia telah tercetak beberapa kali. Era globalisasi akan mempengaruhi sendi-sendi kehidupan manusia, termasuk di bidang pendidikan³ Dalam buku Megatends 2000 karya Naisbit tersebut dideskripsikan tentang berbagai fenomena yang akan terjadi pada era globalisasi. Di antaranya adalah munculnya beberapa perubahan yang mendasar, antara lain, pada abad ke 21 atau abad Millenium, terjadi transformasi peradaban, yakni munculnya beberapa trend, yang sangat fenomenal, antara lain perubahan masyarakat dari masyarakat industri ke masyarakat informasi, dan demokrasi partisipatoris, dari ekonomi nasional menjadi ekonomi dunia yang bebas dan global (world

1 Walaupun Pemimpin Soyvet Michael Gorbacev, telah melakukan kebijakan untuk perbaikan ekonomi dan politin "Negeri beruang Merah" tersebut, dengan kebijakan Glasnots dan Perestroika (Keterbukaan dan Reformasi) tetapi upaya itu tidak membawa hasil, dan akhirnya tuntutan perubahan politik yang kuat, menyebabkan Uni Sovyet Runtuh tahun 1990 awal. Peristiwa itu ditandai oleh lepasnya beberapa Negara yang tergabung dalam Uni Sovyet termasuk Negara-negara yang tergabung dalam aliansi Blok Timur, dan Negara-negara Pakta Warsawa, aliansi pertahanan Negara-negara yang berideologi Komunis di Eropa, blok Sovyet.

2 Peristiwa perubahan politik terbesar dalam sejarah dunia itu, sempat diabadikan oleh kelompok music rock Scorpion, melalui lagu "Wind of Change", yang menggambarkan perubahan yang terjadi di Eropa Timur, terutama di Uni Sovyet.

3 Zainal Abidin, Reformasi Pendidikan Islam: Sebuah Upaya Membangun Kembali Visi Institusi Pendidikan Tinggi Islam, dalam Majalah Akademika, No. 02 Th ke I Edisi Maret 1999, STAIN Jurai Siwo Metro, 1999.

RI'AYAH, Vol. 01, No. 01 Januari-Juni 2016 
economy). ${ }^{4}$ Tampaknya jika melihat fenomena dunia terkini, prediksi Naisbit tersebut benar menjadi kenyataan, karena perubahan yang begitu cepat melahirkan peradaban baru pada abad ke-21, yaitu munculnya era informasi, dan globalisasi, seakan-akan tidak ada lagi "Batas-batas negara" karena informasi begitu cepatnya didapat, dan diakses oleh setiap manusia, serta komunikasi menjadi keutuhan setiap hari dari aktifitas manusia, melintasi batasbatas negeri. Kalau dulu Televisi (TV) dianggap sebagai "Jendela Dunia” karena dianggap sebagai representasi teknologi yang tercanggih pada zamannya. Sekarang telah tergantikan oleh era digital melalui teknologi telepon pintar berbasis Android, dan telah merubah pandangan itu bahwa "Dunia Ada di Genggaman Tangan" atau "Saku Dunia", informasi dibelahan dunia manapun dengan cepat dapat diperoleh oleh manusia yang menggunakan teknologi digital tersebut. Sebagai implikasinya, pada era informasi ini adalah berkembang adagium bahwa siapa yang menguasai media, maka ia akan jadi pemenangnya, dan menguasai dunia.

Namun harus diakui perubahan dramatis tersebut juga membawa ekses negatif bagi manusia, karena kondisi ini memicu kebebasan yang tidak ada batasannya. Perkembangan dunia teknologi informasi dewasa ini telah membawa perubahan mendasar, disamping pengaruh positif, ternyata dampak negatifnya juga sangat besar, bagi mentalitas dan moralitas anak-anak, akibat mudahnya mengakses informasi yang tidak berisikan pesan-pesan baik saja, melainkan juga konten yang merusak moral dan akidah umat juga banyak beredar, seperti pornografi, narkotika, tindak kekerasan, pergaulan bebas dan lain sebagainya. Hal ini pasti membawa dampak dalam jangka panjang bagi perkembangan psikis anak-anak yang sedang belajar dilembaga-lembaga pendidikan. Masalah ini bukan hanya terjadi di Indonesia saja, tetapi menjadi masalah global dalam dunia pendidikan, terutama di negara-negara di kawasan ASEAN, maka diperlukan kerjasama dan komunikasi antar bangsa untuk menanggulangi problematika tersebut, dengan meningkatkan kerjasama di bidang pendidikan serta memperkuat jati diri dalam kebudayaan dan sebagainya.

Pendidikan sangat sentral peranannya dalam menanggulangi ekses negatif dari perkembangan teknologi informasi. Walaupun Negara-negara dikawasan ASEAN sangat majemuk ditinjau dari aspek agama yang dianutnya, akan tetapi kerjasama itu perlu dilakukan untuk membina harmoni di kawasan tersebut, dan membangun sikap saling menghargai antar pemeluk agama. Namun begitu, dengan melihat perkembangan politik yang ada di kawasan ASEAN tampaknya upaya itu, masih memerlukan perjuangan panjang, karena beberapa masalah domestik maupun regional di Negara-negara ASEAN masih cukup banyak, misalnya semangat untuk mewujudkan Masyarakat Ekonomi ASEAN (MEA) 
atau AEC (ASEAN Economic Community) pada akhir tahun 2015 ini dan mewujudkan "Wawasan ASEAN 2020", dan mempercepat terbentuknya integrasi ekonomi ASEAN dalam menghadapi perdagangan bebas antar negaranegara ASEAN. Pada saat makalah ini ditulis, sedang berlangsung Konferensi Tingkat Tinggi (KTT) ke-27 ASEAN di Kuala Lumpur, Malaysia, pada tanggal 21-23 Nopember 2015 yang diikuti oleh seluruh kepala Negara dan pemerintahan negara yang tergabung dalam ASEAN. Salah satu kesepakatan dalam KTT tersebut adalah ditandatanganinya kesepakatan pembentukan Kumunitas ASEAN (MEA/AEC), dan tekad bersama bahwa mulai 1 Januari tahun 2016, sepuluh Negara ASEAN akan menjadi pasar tunggal dan basis produksi. ${ }^{5}$ Diharapkan kerjasama itu segera terwujud sehingga masalah-masalah internasional dikawasan itu segera dapat diselesaikan dengan baik, misalnya masalah ketenagakerjaan antara Indonesia dengan Malaysia dan Singapura, masalah pengungsi Muslim Rohingya dari Myanmar, konflik garis batas antar negara dan lain sebagainya. Pertanyaan berikutnya adalah sudah siapkah negara-negara di kawasan itu, khususnya Indonesia dalam menghadapi pasar bebas ASEAN dalam konteks MEA? Dalam makalah ini akan mengkajinya dalam perspektif kerjasama dibidang pendidikan dalam Masyarakat Ekonomi ASEAN, dan dalam konteks realitas kesejarahan organisasi regional ASEAN.

\section{Kerjasama Bangsa-Bangsa di Kawasan Asia Tenggara dalam MEA}

Sejak berdiri tahun 1967 di Bangkok Thailand, melalui sebuah Deklarasi Bangkok, tampaknya ASEAN (Association of South East Asian Nations/Perhimpunan Bangsa-Bangsa Asia Tenggara), 6 menjadi wadah komunikasi dan kerjasama yang cukup efektif dalam menyuarakan agenda-agenda penting yang terjadi di level politik internasional. Dengan semakin banyaknya anggota ASEAN sekarang, kerjasama regional di kawasan itu akan semakin dibutuhkan dan semakin penting untuk memperkuat jalinan diplomasi, dan pertukaran pelajar, kerjasama kebudayaan, kerjasama di bidang pendidikan, ekonomi dan sebagainya. Belajar

\footnotetext{
5 Republika. co.id, KTT ASEAN Sepakati Masyarakat Ekonomi ASEAN, Ahad 22 Nopember 2015, diakses tanggal 22 Nopember 2015.

${ }^{6}$ ASEAN didirikan di Bangkok tanggal 5 Agustus 1967 dengan persetujuan atau sering disebut Deklarasi Bangkok, antara lima Negara pendiri organisasi tersebut yaitu Indonesia, Singapura, Thailand, Malaysia, dan Filipina. Negara-negara yang berhaluan komunis di kawasan itu saat itu belum bergabung, misalnya Myanmar, Laos, Kamboja dan Vietnam. Setelah Merdeka Burunei ikut bergabung dengan ASEAN tahun 1984, dan beberapa Negara lainnya menyusul bergabung misanya Laos, dan Myanmar bergabung pada tahun 1997, dan Kamboja menjadi Negara ke-10 bergabung pada tahun 1998. Secara berturut-turut dapat negara lain yang bergabung ke dalam ASEAN antara lain, Brunei Darussalam tanggal 7 Januari 1994, Vietnam pada Sejak 28 Juli 1995, Laos dan Myanmar secara bersama-sama pada 23 Juli 1997 dan Kamboja bergabung tanggal 16 Desember 1998. Sejak awal organisasi ASEAN dibentuk, bukan merupakan organisasi yang bersifat politis dan militer. Seiring dengan perkembangan terakhir, ASEAN juga mencoba menjajaki perluasan anggota kepada beberapa Negara tetangga di sekitar ASEAN, antara lain Bangladesh, Palau, Papua Nugini, Republik China (Taiwan) dan Timor Leste. Wikipedia.org. Perhimpunan Bangsa-Bangsa Asia Tenggara, diakses tanggal 20 Nopember 2015. Lihat Juga Lutfi Zen, Blog, Sejarah dan Tujuan Berdirinya ASEAN, diakses tanggal 21 Nopember 2015.
}

RI'AYAH, Vol. 01, No. 01 Januari-Juni 2016 
dari kerjasama yang sama, dari beberapa Negara-negara di kawasan Eropa, yang tergabung dalam MEE (Masyarakat Ekonomi Eropa), dan hingga sekarang masih cukup solid bahkan telah menggunakan sistem "Mata Uang Tunggal " Euro dan merubah MEE menjadi EU (European Union/Uni Eropa), dan mempunyai 28 negara anggota lebih besar dari ASEAN.

Dalam dokumen pendirian ASEAN dapat dilihat bahwa tujuan pendirian organisasi tersebut, berdasarkan Deklarasi Bangkok 1967 ada tujuh. Pertama, mempercepat pertumbuhan ekonomi dan kemajuan sosial budaya, melalui usaha-usaha didalam semangat kesetaraan dan kebersamaan, memperkuat pondasi untuk kesejahteraan dan perdamaian di Asia Tenggara. Kedua, memajukan perdamaian dan stabilitas regional dengan menghormati keadilan dan supremasi hukum dalam hubungan antar Negara-negara dalam satu kawasan dan kepatuhan terhadap Piagam PBB. Ketiga, memajukan kerjasama dan saling membantu kepentingan bersama dalam bidang ekonomi, sosial, budaya, teknik, ilmu pengetahuan dan teknologi, serta bidang administrasi. Keempat, memajukan kerjasama dalam bidang pertanian, industri, perdagangan, pengankutan (transportasi), dan komunikasi serta meningkatkan taraf hidup manusia atau masyarakat di kawasan Asia Tenggara. Kelima, memberikan bantuan satu sama lain dalam berbagai fasilitas pelatihan dan penelitian dalam bidang pendidikan, pekerjaan, teknik dan administrasi. Keenam, mempromosikan sistem pendidikan di Asia Tenggara (South East Asian Studies). Ketujuh, memelihara kerjasama yang lebih erat dan saling menguntungkan dengan organisasi-organisasi internasional dan regional. ${ }^{7}$

Berdasarkan tujuan ASEAN tersebut semakin memperteguh bahwa organisasi tersebut bukan merupakan aliansi militer maupun aliansi politik, tetapi lebih menekankan aspek kerjasama dan kemajuan bersama bagi negaranegara di kawasan Asia Tenggara. Salah satu tujuan yang berkaitan dengan pendidikan adalah kerjasama di bidang ilmu pengetahuan, dan tekhnologi, dan bidang penelitian. Termasuk tujuan ke-7 yaitu mempromosikan sistem pendidikan di Asia Tenggara. Sekarang Negara-negara yang tergabung dalam ASEAN berjumlah 10 negara yaitu Indonesia, Malaysia, Singapura, Thailand, Filipina, Brunei Darussalam, Vietnam, Myanmar, Laos dan Kamboja. ASEAN adalah organisasi organisasi internasional yang sangat besar, jika dijumlahkan secara keseluruhan luas wilayahnya mencapai 1,7 juta mil atau sekitar 4,5 juta kilometer persegi dengan jumlah populasi yang ada di dalamnya sekitar setengah milyar orang, dan menjadikan ASEAN sebagai organisasi regional terbesar di Asia.

Sebenarnya semangat dalam MEA (Masyarakat Ekonomi ASEAN) telah dirintis dalam konteks diplomasi negara di kawasan ASEAN dalam waktu yang lama. Sebelum menjadi MEA atau atau AEC (ASEAN Economic Community),

7Sukasosial.blogspot, Mengenali Pengertian, Sejarah dan Tujuan ASEAN, diakses pada tanggal 22 Nopember 2015.

RI'AYAH, Vol. 01, No. 01 Januari-Juni 2016 
gagasan perlunya membentuk Pasar Bebas atau Perdagangan Bebas di kawasan Asia Tenggara dalam bentuk AFTA (ASEAN Free Trade Area), yakni persetujuan oleh ASEAN mengenai sektor produksi lokal di seluruh Negara ASEAN. 8 Dengan demikian AFTA adalah hubungan perdagangan bebas antara Negaranegara anggota ASEAN untuk menciptakan kawasan pasar bebas dengan tujuan untuk meningkatkan daya saing antara negara-negara ASEAN. Pembentukan AFTA sesungguhnya telah lama didirikan di Singapura tahun 1992 dalam kesepakatan KTT ASEAN ke IV untuk membentuk zona perdagangan bebas. AFTA dipandang perlu untuk meningkatkan daya saing ekonomi kawasan regional ASEAN yang direncanakan dalam waktu 9 tahun (1993-2002). Rencana ini dijalankan dengan cara menghapus biaya tariff (bea masuk 0-5\%), maupun biaya tarif bagi negara anggota ASEAN. Dengan cara ini AFTA berharap ASEAN menjadi basis produksi dunia serta menciptakan pasar regional bagi 500 juta penduduk ASEAN. ${ }^{9}$ Tujuan utama AFTA adalah untuk meningkatkan daya saing ekonomi Negara-negara ASEAN dengan menjadikan ASEAN sebagai basis produk dunia dan untuk menarik investor asing dan meningkatkan perdagangan antar Negara anggota ASEAN. Perkembangan terakhir AFTA disepakati penghapuskan bea masuk semua barang impor pada tahun 2010 bagi Brunei Darussalam dan tahun 2015 bagi Indonesia, Malaysia, Pilipina, Singapura, Thailand, Kamboja, Laos, Myanmar dan Vietnam.

Namun AFTA juga mendapatkan kritik, karena meskipun telah didirikan dalam ASEAN Summit ke-4 tahun 1992 di Singapura, dan bertekad akan membentuk kawasan pasar bebas ASEAN dalam jangka 15 tahun, berarti harusnya kalau dihitung akan efektif pada tahun 2007 yang lalu. Namun kenyataannya AFTA ini akan aktif pada tahun 2015, berarti 22 tahun kemudian. ${ }^{10}$ Ini bisa dimaklumi karena membentuk sebuah kawasan pasar bebas tentu tidak mudah, karena dipengaruhi oleh beberapa faktor global, misalnya faktor stabititas moneter sebuah negara, stabilitas politik, dan factor-faktor fundamental ekonomi negara anggota dari ASEAN itu sendiri.

Semangat dalam AFTA itu kemudian menjelma dengan terbentuknya ASEAN Economic Community (AEC) atau Masyarakat Ekonomi ASEAN (MEA) pada saat KTT ASEAN ke-9, bulan Oktober 2003 di Bali Indonesia. Para pemimpin ASEAN mendeklarasikan bahwa MEA merupakan tujuan integrasi ekonomi regional (Bali Concord II) pada tahun 2020, dan mempercepatnya menjadi tahun 2015, dan bertekad mengimplementasikan MEA mulai tanggal 1 Januari 2016. Selain MEA juga dibentuk Komunitas Keamanan ASEAN dan Komunitas Sosial dan Budaya. Ketiga pilar tersebut diharapkan dapat bekerja secara erat dalam pembentukan Komunitas ASEAN tahun 2020, yakni komunitas

\footnotetext{
8 Wikipedia, AFTA (ASEAN Free Trade Area) diakses tanggal 23 Nopember 2015.

9 www.pengertianahli .com, Pengertian, Tujuan dan Anggota AFTA, diakses tanggal 23 Nopember 2015.

10 Hima Manajemen FE UNY wordpress.com, Tantangan dan Keuntungan AFTA 2015 untuk Indonesia, diakses tanggal 23 Nopember 2015.
}

RI'AYAH, Vol. 01, No. 01 Januari-Juni 2016 
ASEAN yang terintegrasi antara Ekonomi, Sosial-Budaya dan Keamanan. Kesepakatan Bali Concord II, selanjutnya ditindak lanjuti dalam beberapa forum ASEAN Summit secara berturut-turut, dilaksanakan di tahun 2006 dalam pertemuan ke-38 Menteri Ekonomi ASEAN di Kuala Lumpur sepakat untuk menyusun "Cetak Biru" (Bule Print), untuk mempercepat pembentukan MEA pada tahun 2015 sesuai dengan Bali Concord II. Isi dari Blue Print MEA/AEC itu antara lain berisi empat pilar utama:

1. ASEAN sebagai pilar pasar tunggal dan berbasis produksi tunggal yang didukung elemen aliran bebas barang dan jasa, tenaga kerja terdidik dan aliran modal yang lebih luas.

2. ASEAN sebagai kawasan dengan daya saing ekonomi yang tinggi, dengan elemen peraturan dan kompetisi, perlindungan konsumen, hak atas kekayaan intelektual, pengembangan infrastructure, perpajakan dan ecommerse.

3. ASEAN sebagai kawasan pengembangan ekonomi yang merata dengan elemen pengembangan usaha kecil dan menengah dan prakarsa integrasi ASEAN untuk Negara CMLV (Cambodia, Myanmar, Laos dan Vietnam).

4. ASEAN sebagai kawasan yang terintegrasi secara penuh dengan perekonomian global dengan pendekatan koheren dalam hubungan ekonomi di luar kawasan dan meningkatkan peran serta dalam jejaring produksi global.11

Dan pada KTT ASEAN (ASEAN Summit) ke 12 di Cebu, Philipina 13 Januari 2007. Dalam KTT tersebut berhasil menegaskan komitmen untuk membentuk MEA pada tahun 2015 sejalan dengan VISI ASEAN 2020 dan Bali Concord II, dengan kesepakatan yang terkenal dengan "Cebu declaration on the acceleration of the establishment of an ASEAN", dan mempertegas pembentukan MEA tahun 2015, dan menjadikan kawasan Asteng menjadi kawasan bebas aliran barang dan jasa, investasi, dan tenaga terampil, serta aliran modal yang lebih bebas. Sebagai landasan legal dan konstitusional bagi anggota Negara ASEAN maka disusunlah ASEAN Charter (Piagam ASEAN), dan Indonesia telah meratifikasi Piagam Tersebut dengan menerbitkan UU No. 30 tahun 2008 sebagai payung berbagai perjanjian kerjasama di tingkat ASEAN.12 Dan hasil KTT ASEAN terakhir pada bulan Nopember 2015 ini telah disepakati bahwa mulai tahun 2016, MEA mulai di laksanakan dinegara ASEAN. Konferensi Tingkat Tinggi (KTT) ke-27 ASEAN di Kuala Lumpur, Malaysia, pada tanggal 21-23 Nopember 2015 yang diikuti oleh seluruh kepala Negara dan pemerintahan Negara, semakin mempertegas kesepakatan MEA yang sebentar lagi dilaksanakan pada tanggal 1 Januari 2016.

11 www. Academia. Edu. Faizal Malik, Latar Belakang terbentuknya MEA atau AEC 2015, diakses 23 Nopember 2015.

12Dirjen Pengolahan dan Pemasaran Hasil Pertanian, Pphp.pertanian. go.id/news, Sejarah Singkat Terbentuknya Masyarakat Ekonomi ASEAN (MEA), diakses pada tanggal 23 Nopember 2015.

RI'AYAH, Vol. 01, No. 01 Januari-Juni 2016 


\section{Kerjasama di Bidang Pendidikan: Peluang dan Tantangan}

Salah satu implikasi AFTA ataupun MEA adalah kesiapan negara dikawasan ASEAN termasuk Indonesia menghadapi persaingan regional dalam berbagai aspek, termasuk pendidikan. Hal ini terjadi karena salah satu efek AFTA adalah setiap warga anggota ASEAN bisa sekolah atau bekerja di tiap negara Asean..$^{13}$ Indonesia akan menghadapi serbuan para pekerja asing hasil output pendidikan dari negara maju seperti Singapura, tentunya perlu pemikiran serius dari pemerintah Indonesia untuk menyiapkan tenaga yang berdaya saing tinggi menghadapi era pasar bebas itu. Karena hingga saat ini kondisi pendidikan di tanah air masih banyak memerlukan pembenahan, misalnya tidak macth-nya lulusan dengan lapangan kerja, seorang sarjana Agama, atau sarjana Elektro malah bekerja di pertanian, bahkan banyak perusahaan yang malah merekrut tenaga kerja dari luar karena dianggap memiliki kompetensi yang lebih baik. ${ }^{14}$

Untuk meminimalisir kesenjangan mutu output dunia pendidikan maka mutlak dilakukan kerjasama antar Negara ASEAN dalam bidang pendidikan, misalnya melakukan pertukaran mahasiswa (student exchange), penelitian bersama, muhibah dalam bidang pendidikan dan budaya, dialog kawasan dan lain sebagainya. Hal ini dimaksudkan supaya terjalin komunikasi dan kesepahaman antar negara-negara dikawasan tersebut, agar terjadi kesetaraan dan persaingan yang sehat dalam tataran dunia kerja, dan pemerintah Indonesia mutlak harus berupaya keras meningkatkan kualitas Sumber Daya Manusia (SDM) melalui jalur pendidikan yang bermutu.

Berdasarkan hasil Survey Indeks Sumber Daya Manusia (Human Development Indexs/HDI), pada tahun 1999---mungkin sekarang sudah berubah lebih baik----menempatkan kualitas SDM Indonesia berada pada ranking bawah dibandingkan dengan Negara-negara di kawasan Asia Tenggara, jauh di bawah Malaysia, Vietnam, Brunei, dan Thailand. Menurut laporan HDI tersebut waktu itu, Indonesia berada di ranking 102 dari 164 negara di dunia. Lebih rendah dibandingkan Negara Malaysia yang menempati ranking 53, Singapura ranking 34, Thailand ranking 52, dan Brunei Darussalam ranking ke-36. ${ }^{15}$ Kondisi ini kemungkinan telah berubah, karena survey tersebut dilakukan ketika Indonesia, dilanda krisis moneter dan politik, bisa jadi sekarang lebih baik atau sebaliknya. Kondisi ini jelas berbanding terbalik dengan era tahun 1960-an hingga tahun

${ }^{13}$ Faherza Maulana Faisal blog spot, AFTA diakses tanggal 23 Nopember 2015.

14 Hima Manajemen FE UNY wordpress.com, Tantangan dan Keuntungan AFTA 2015 untuk Indonesia, diakses tanggal 23 Nopember 2015.

15 Boediono, "Pembangunan Pendidikan Dalam Abad ke 21: mencari Paradigma Baru Sistem Pendidikan Nasional Menghadapi Millenium Ketiga", Makalah dipresentasikan dalam Seminar Nasional, di Primagama Yogyakarta, Tahun 1999.

RI'AYAH, Vol. 01, No. 01 Januari-Juni 2016 
1970-an, Indonesia pernah menjadi salah satu tujuan mahasiswa asal Thailand dan Malaysia untuk belajar bahkan pernah mengirim tenaga-tenaga guru untuk mengajar di sekolah-sekolah di Malaysia. ${ }^{16}$

Menurut data terakhir tentang Indeks Pembangunan Manusia (IPM) pada tahun 2013, berdasarkan laporan dari Sekretaris Direktorat Jenderal Perguruan Tinggi di Jakarta, bahwa Indonesia menempati 121 dari 185 negeri dengan indeks Pembangunan Manusia (IPM) dengan angka 0,629. Bersama dengan itu Indonesia tertinggal dari dua negeri tetangga ASEAN yaitu Malaysia (peringkat 64) dan Singapura (peringkat 18), sedangkan IPM di kawasan Asia Pasifik, yaitu 0,683.17 Intinya berarti Indonesia harus berjuang lebih keras lagi untuk meningkatkan IPM-nya.

Dalam konteks kekinian, bonus Demografi Indonesia tidak akan memberikan keuntungan apapun tanpa adanya perbaikan kualitas SDM. Data dari ASEAN Productivity Organization (APO) menujukkan dari 1000 tenaga kerja Indonesia hanya sekitar 4,3\% terampil, sadangkan Filipina 8,3\%, Malaysia 32,6\% dan Singapura 34, 6\%. Berdasarkan struktur pasar tenaga kerja didominasi oleh pekerja lulusan SD, (70\%), SMP (10\%) dan SMA (13\%), sementara lulusan perguruan tinggi hanya $7 \%$, dimana sekarang dunia kerja mensyaratkan lulusan perguruan tinggi. Data terakhir untuk tenaga kerja lulusan S1 sudah mencapai 12\%. Hal ini berbanding terbalik dengan Malaysia dengan sebagian penduduknya lulusan S1. Kesempatan memperoleh pendidikan secara merata di seluruh Indonesia sulit dilakukan, kesadaran untuk menempuh pendidikan tinggi sangat rendah. Kondisi ini menyebabkan tenaga kerja Indonesia hanya dilirik sebagai buruh dan tenaga kerja kasar (TKI dan TKW), di pasar tenaga kerja Internasional. 18

Di samping kondisi real pendidikan dan SDM Indonesia tersebut sebenarnya Indonesia juga mempunyai peluang atau potensi yang besar dalam menyongsong MEA ditahun 2016. Pertama, Indonesia merupakan potensi pasar potensial, karena memiliki jumlah penduduk terbesar sekitar $40 \%$ dari Negara diregional ASEAN, dan mempunyai wilayah luas. Hal ini dapat menjadikan Indonesia sebagai Negara dengan ekonomi yang produktif, ekonomi kreatif, dan dinamis yang dapat memepimpin pasar ASEAN di masa depan, dengan kesempatan penguasaan pasar dan investasi. Kedua, Indonesia merupakan Negara tujuan investor ASEAN, proporsi investasi itu mencapai $43 \%$ atau hamper tiga kali lebih tinggi dari rata-rata proporsi investasi Negara ASEAN lain yaitu hanya $15 \%$ di kawasan Intra-ASEAN. Ketiga, Indonesia berpeluang

16 Zainal Abidin, “Rekonstruksi Sistem Pendidikan Nasional: Menelusuri Problematika Peningkatan Kualitas SDM dan Pembangunan Karakter Bangsa", dalam Jurnal Forum Tarbiyah, Vol. 2 No.2 November 2004, STAIN Pekalongan.

17 Dina Nurhayati wordpress.com, Dunia Pendidikan Indonesia Menghadapi Masyarakat Ekonomi ASEAN 2013, diakses 23 Nopember 2015.

18 Berita php. Pertanian. Go.id, Peluang dan Tantangan Indonesia Sambut MEA, diakses 22 Nopember 2015.

RI'AYAH, Vol. 01, No. 01 Januari-Juni 2016 
menjadi Negara pengespor, dimana nilai ekspor Indonesia ke Negara IntraASEAN hanya 18-19\% sedangkan keluar ASEAN berkisar 80-82\%, ini berarti peluang mengingkatkan ekspor melalui MEA terbuka lebar. Keempat, Liberalisasi perdagangan barang ASEAN akan menjamin kelancaran arus barang untuk pasokan bahan baku maupun bahan jadi di kawasan karena hambatan tarif dan non-tarif sudah tidak ada lagi. Kelima, Indonesia dengan jumlah populasi terbesar akan memperoleh keunggulan tersendiri yang disebut sebagai "Bonus Demografi". Perbandingan jumlah pendudukan produktif Indonesia dengan Negara ASEAN lainnya adalah 38:100, yang intinya bahwa setiap 100 penduduk ASEAN, 38 adalah warga Negara Indonesia. Bonus Demografi ini masih bisa dinikmati hingga setidaknya pada tahun 2035, yang diharapkan jumlah penduduk produktif bisa menopang pertumbuhan ekonomi dan meningkatkan perndapatan perkapita. ${ }^{19}$

Strategi pendidikan nasional supaya SDM Indonesia dapat bersaing dalam dunia kerja global, paling tidak harus mengacu pada faktor penentu kemajuan suatu bangsa atau negara, yaitu: penguasaan innovasi (45\%), penguasaan jaringan $25 \%$, penguasaan teknologi $20 \%$, dan penguasan kekayaan sumber daya alam hanya $10 \%$. Maka pendidikan di Indonesia harus lebih menekankan pada tiga penguasaan tersebut, yaitu penguasaan inovasi, jaringan, dan teknologi, disamping SDA yang melimpah. ${ }^{20}$ Strategi ini penting, karena MEA sudah ada didepan mata dan kekuatan Masyarakat Ekonomi ASEAN adalah ketiga terbesar setelah Jepang dan Tiongkok. Dengan demikian untuk menyambut trend MEA tersebut pendidikan di Indonesia harus mampu menciptakan SDM yang kritis, peka, ulet dan terampil dalam menghadapi tantangan dan perubahan yang akan terjadi di dunia pendidikan.

Dalam konteks pendidikan tinggi, banyak perguruan tinggi yang siap menghadapi persaingan pasar bebas ASEAN. Barangkali perguruan tinggi sepertri UI, UGM, ITB, ITS sudah lama menjadi tempat belajar beberapa mahasiswa dari berbagai negeri, bukan terbatas hanya dikawasan regional ASEAN, bahkan beberapa Negara lain dari kawasan benua Asia lainnya termasuk benua Afrika. Walaupun dalam dekade terakhir justeru banyak mahasiswa asal Indonesia yang belajar di Negara-negara tetangga, misalnya di Malaysia, Singapura, Thailand dan Pilipina. Untuk level perguruan tinggi agama Islam, barangkali kerjasama dengan Negara-negara Timur Tengah, Amerika, Kanada, juga sudah terjalin lama. Bahkan beberapa PTKI, seperti IAIN Sumatera Utara, dalam tahun 1980-hingga sekarang banyak mahasiswanya yang berasal dari Malaysia. Semakin terbukanya akses pendidikan tinggi juga menentukan informasi perguruan tinggi tersebut, berpeluang menerima mahasiswa yang

19 Php.pertanian Direktorat Jenderal Pengolahan dan Pemasaran Hasil Pertanian, diakses tanggal 23 Nopember 2015.

20 Dina Nurhayati, Dunia Pendidikan Indonesia Menghadapi Masyarakat Ekonomi ASEAN 2013, wordpress.com, diakses 23 Nopember 2015.

RI'AYAH, Vol. 01, No. 01 Januari-Juni 2016 
berasal dari kawasan Asia Tenggara. Misalnya beberapa waktu lalu juga telah ada penjajakan dari mahasiswa yang berasal dari Patani Thailand, yang ingin studi di STAIN Jurai Siwo Metro, bahkan di IAIN Raden Intan sudah ada beberapa angkatan. Kemudian UIN yang paling banyak jumlah mahassiswa asingnya adalah UIN Maulana Malik Ibrahim Malang. Menurut informasi dari rektornya, paling tidak terdapat mahasiswa asing yang belajar disana, berasal dari 18 negara, di Asia Tenggara, Timur Tengah, Afrika, Rusia, dan sebagainya. Hal yang sama juga dilakukan diberbagai UIN, seperti UIN Jakarta, UIN Yogyakarta, UIN Makassar, dan UIN Sumatera Utara, UIN Surabaya, dan sebagainya. Bahkan pondok pesantren, misalnya pondok Gontor Darussalam Ponorogo, sudah lama menjadi tempat belajar beberap pelajar dari Thailand, Malaysia, Brunei Darussalam, dan lain sebagainya, termasuk pondok lainnya seperti pondok Az-Zaitun, dan lain-lainnya.

Pada prinsipnya pendidikan tinggi Islam di Indonesia, maupun lembaga pendidikan Islam lainnya, secara umum sesungguhnya telah siap menghadapi persaingan dalam pasar bebas Asia Tenggara dalam MEA 2016 mendatang. Karena secara realitas ada beberapa Perguruan Tinggi baik umum maupun PTKIN (Perguruan Tinggi Keagamaan Islam Negeri) yang secara meyakinkan telah berani membuka kelas-kelas internasional, dan telah mempersiapkan SDM pengajarannya sesuai dengan standard dan kualifikasi Internasional. Ke depan tentunya persaingan global akan semakin besar dampaknya, dan perlu persiapan yang matang, paling tidak alumni PTKIN harus dibekali kemampuan intelektual yang baik termasuk kemampuan penguasaan bahasa Asing terutama Inggris dan Arab mutlak harus dikuasai agar mampu berkompetisi dengan output pendidikan sejenis dari negara-negara di kawasan ASEAN.

\section{Penutup}

Dengan munculnya MEA atau AEC (ASEAN Economic Community) semakin membuka peluang sekaligus tantangan bagi bangsa Indonesia untuk siap bersaing, secara fair dalam konteks pasar bebas Asia Tenggara. Untuk itu dibutuhkan penguatan kualitas SDM dan memperbaiki sistem pendidikan yang berorientasi global, terutama pendidikan tinggi agama Islam atau PTKIN dituntut lebih responsif, hal ini disebabkan karena mayoritas penduduk Indonesia beragama Islam, maka keberadaan PTKIN sangat penting yang bisa menjadi alternatif perguruan tinggi dengan taraf internasional, dan menjadi kiblat bagi pengkajian Islam dunia, sekaligus menjadi pusat ilmu pengetahuan Islam dunia. Melalui MEA bisa dijadikan sebagai batu loncatan untuk mengembangkan pendidikan tinggi Islam secara mondial, bahkan bukan hanya di kawasan Asia Tenggara, tetapi di seluruh penjuru dunia. Tampaknya upaya itu membutuhkan waktu yang panjang, tetapi secara faktual sekarang telah dimulai dan dirintis oleh beberap PTKIN seperti UIN dan beberapa IAIN, juga STAIN.

RI'AYAH, Vol. 01, No. 01 Januari-Juni 2016 


\section{Daftar Pustaka}

Berita php. Pertanian. Go.id, Peluang dan Tantangan Indonesia Sambut MEA, diakses 22 Nopember 2015.

Boediono, "Pembangunan Pendidikan Dalam Abad ke 21: mencari Paradigma Baru Sistem Pendidikan Nasional Menghadapi Millenium Ketiga", Makalah dipresentasikan dalam Seminar Nasional, di Primagama Yogyakarta, Tahun 1999.

Dina Nurhayati wordpress.com, Dunia Pendidikan Indonesia Menghadapi Masyarakat Ekonomi ASEAN 2013, diakses 23 Nopember 2015.

Dirjen Pengolahan dan Pemasaran Hasil Pertanian, Pphp.pertanian. go.id/news, Sejarah Singkat Terbentuknya Masyarakat Ekonomi ASEAN (MEA), diakses pada tanggal 23 Nopember 2015.

Hima Manajemen FE UNY wordpress.com, Tantangan dan Keuntungan AFTA 2015 untuk Indonesia, diakses tanggal 23 Nopember 2015.

John D Naisbit and Patricia Aburdene, Megatrends 2000, USA: Penguin Book, 1990.

Lutfi Zen, Blog, Sejarah dan Tujuan Berdirinya ASEAN, diakses tanggal 21 Nopember 2015.

Faherza Maulana Faisal blog spot, AFTA diakses tanggal 23 Nopember 2015.

Hima Manajemen FE UNY wordpress.com, Tantangan dan Keuntungan AFTA 2015 untuk Indonesia, diakses tanggal 23 Nopember 2015.

Php.pertanian Direktorat Jenderal Pengolahan dan Pemasaran Hasil Pertanian, diakses tanggal 23 Nopember 2015.

Republika. co.id, KTT ASEAN Sepakati Masyarakat Ekonomi ASEAN, Ahad 22 Nopember 2015, diakses tanggal 22 Nopember 2015.

Sukasosial.blogspot, Mengenali Pengertian, Sejarah dan Tujuan ASEAN, diakses pada tanggal 22 Nopember 2015.

Wikipedia.org. Perhimpunan Bangsa-Bangsa Asia Tenggara, diakses tanggal 20 Nopember 2015.

, AFTA (ASEAN Free Trade Area) diakses tanggal 23 Nopember 2015.

www. Academia. Edu. Faizal Malik, Latar Belakang terbentuknya MEA atau AEC 2015, diakses 23 Nopember 2015.

Pengertian, Tujuan dan Anggota AFTA, www.pengertianahli .com, diakses tanggal 23 Nopember 2015.

Zainal Abidin, Reformasi Pendidikan Islam: Sebuah Upaya Membangun Kembali Visi Institusi Pendidikan Tinggi Islam, dalam Majalah Akademika, No. 02 Th ke I Edisi Maret 1999, STAIN JUrai Siwo Metro, 1999.

-------, "Rekonstruksi Sistem Pendidikan Nasional: Menelusuri Problematika Peningkatan Kualitas SDM dan Pembangunan Karakter Bangsa", dalam Jurnal Forum Tarbiyah, Vol. 2 No.2 November 2004, STAIN Pekalongan. 